\title{
SIMULTANEITY OF TIME AND WEATHER IN 'EXOTIC' CLIMATES: THE EXPERIENCE OF FRENCH WRITERS IN AFRICA AND THE AMERICAS
}

\author{
DAVID SCOTT
}

This paper sets out to explore the ways in which certain climates (desert or jungle) perceived by western travellers to be 'exotic' affect their perceptions of time and weather (in French the word 'temps' covers the meaning of both English words). A particular effect repeatedly noted by nineteenth and twentieth-century French travel writers is that of simultaneity, either of weather patterns in certain mountain (vertical) or desert (horizontal) environments, and/or of a telescoping or dilation of linear temporal sequence. The disorientation experienced as a result of this, combined with a lack of narrative or historical reference in the spaces travelled through, leads typically to a feeling of lack of time or the illusion of entry into a mythical time. The implications of this phenomenon will be explored in the work of three French travel books: Eugène Fromentin's Un Eté dans le Sahara,${ }^{1}$ Henri Michaux's Ecuador ${ }^{2}$ and Jean Baudrillard's Amérique. ${ }^{3}$

The theoretical frame within which this topic will be explored is that of semiotics, in particular as it is elaborated by Charles Sanders Peirce in his posthumously collected papers. ${ }^{4}$ Travel writers are ineluctably confronted with the problem of signs on the level both of their recognition and subsequently of their interpretation. ${ }^{5}$ Peirce's elaborate taxonomy of what he calls representamens facilitates a finer gauging of the way qualities or sensations - in particular qualisigns (temperature, colour, humidity, luminosity) shade into more fully articulated and recognizable forms (clouds, water, vegetation). However signs are construed, though, and their use conventionalized, they are of course artificial constructs and betray to a greater or lesser extent a particular world view,

1. Eugène Fromentin, Un Eté dans le Sahara (Paris: Conard, 1938, first pub. 1854).

2. Henri Michaux, Ecuador (Paris: Gallimard, 1968, first pub. 1929).

3. Jean Baudrillard, Amérique (Paris: Grasset, 1986).

4. Charles S. Peirce, Collected Papers, vols. 7 and 8, ed. Arthur W. Burks (Cambridge, Mass: Harvard University Press, 1966).

5. See the distinction between the semiological and the hermeneutic made by Michel Foucault in the preface of Les Mots et les choses (Paris: Gallimard, 1966). 
based on the culture or ethos within which they are framed. As European writers operating within a time span stretching from the early colonial (Fromentin) to the high colonial (Michaux) to the post-colonial (Baudrillard) period, the writers studied here show a progressively heightened consciousness of what is at stake in representing the foreign or exotic scene, the term 'exotic' being itself recognized from the start of the twentieth century as a symptom of colonialism. This paper then, while attending to the categorical problems posed by 'exotic' experience, will also try to be attentive to the inevitable colonialist over-determination to which such categorization submits time and space and the material world. The focus on French texts is partly a function of the exceptional theoretical lucidity travel writers within the Gallic tradition bring to bear upon travel experience.

For European writers living in a predominantly temperate climate, travelling to tropical or equatorial places, either desert or jungle, brought with it not only a shift into an extreme climate but also a different experience of time and weather. Intermediate diurnal stages, such as dawn and dusk, were radically reduced, and gradual seasonal change much more abruptly instituted. Changes in weather, like those of season, were more sudden and new ways of dealing with them had to be elaborated. Some writers (such as Eugène Fromentin) welcomed this challenge as an authentic part of experiencing other climates and places while for others (such as Henri Michaux) it was an alienating and disturbing disruption preventing full appreciation of the other or the exotic. Whatever the response, however, the confrontation with different temporal, seasonal and meteorological modes in exotic climates led to an interrogation of conventional western responses to environment change that would profoundly impact on the travel experience of French writers.

For Eugène Fromentin (1820-1876), painter and art critic as well as a travel writer, the attraction of the North African desert was in large part a function of the challenge it posed to conventional European representation of time, space and light. As a painter, Fromentin responded to this challenge by meditating profoundly on how to represent elemental phenomena in the quasi-abstract terms in which they were experienced. Hence his interrogation of light, shadow, colour and texture, a questioning that is elaborated theoretically in his travel writing as well as practically in his work as an artist. As both artist and writer it is interesting to see how solutions to the problem of expressing this totally different experience of light and time are expressed either in figurative, symbolic terms, or more abstractly through patterns of light and weather.

In the case of figurative representation, a single or small group of figures is perceived as itself encapsulating in plastic, pictorial terms both temporal and

6. See Victor Segalen, Essai sur l'exotisme (Fontefroide: Fata Morgana, 1978). 
spatial dimensions, an over-layering of signifying levels that, as it were, thickens the symbolic stratum of the object, giving it a quasi-mythical dimension. So, for example, in Un Eté dans le Sahara, the essence of the desert walks out towards Fromentin in the form of a young woman carrying a water jar, her precocious youth and richness of clothing contrasting with the premature age of the old man escorting her:

Les palmiers, les premiers que je voyais; ce petit village couleur d'or, enfoui dans des feuillages verts et déjà chargés des fleurs blanches du printemps; une jeune fille qui venait à nous, en compagnie d'un vieillard, avec le splendide costume rouge et les riches colliers du désert, portant une amphore de grès sur sa hanche nue; cette première fille à la peau blonde, belle et forte, d'une jeunesse précoce, encore enfant et déjà femme; ce vieillard abattu, mais non défiguré, par une vieillesse hâtive; tout le désert m'apparaissant ainsi dans toutes ses formes, dans toutes ses beautés et dans tous ses emblèmes, c'était pour la première, une étonnante vision. ${ }^{7}$

The 'étonnante vision' the scene constitutes for Fromentin, as I shall presently show, corresponds exactly to what Jean Baudrillard, a century later, reformulates as the 'vision anthologique' that French travel writers from the nineteenth century onwards would seek in the desert environment. This 'vision anthologique' would, as the lyrical accumulation of emblems in the last part of this passage shows, combine a range of potential interpretative, hermeneutic possibilities with a multiplicity of qualities that in their vividness become almost separated from their object. So it is the presence of signs as formes, beautés, or emblemes - what the semiotician Charles S. Peirce describes as qualisigns (signs of quality) - as much as agents of semiosis that is of importance to Fromentin here. It will correspondingly lead Fromentin to adopt a more purely aesthetic and abstract approach to representing signs of time and weather, the sign's symbolic reverberations inviting much less urgent interpretation. In this way, Fromentin aims to maximize the reader/viewer's immersion in and enjoyment of the sign regardless of its ultimate symbolic importance.

It is for this reason that Fromentin's text Un Eté dans le Sahara is as much a meditation on qualisigns as an account of his travels in the desert. So when Fromentin interrogates the peculiar silence of the desert, he discovers in it qualities as valuable to the artist as any symbolic connotations:

Le silence est un des charmes les plus subtils de ce pays solitaire et vide. Il communique à l'âme un équilibre que tu ne connais pas, toi qui as toujours vécu dans le tumulte; loin de l'accabler, il la dispose aux pensées légères. On croit qu'il représente l'absence du bruit, comme l'obscurité résulte de l'absence de la lumière: c'est une erreur. Si je puis comparer les sensations de l'oreille à celles de la vue, le silence répandu sur les grands espaces est plutôt une sorte de transparence aérienne,

7. Fromentin, p. 7. 
qui rend les perceptions plus claires, nous ouvre le monde ignoré des infiniment petits bruits, et nous révèle une étendue d'inexprimables jouissances. ${ }^{8}$

Like other English and French painters who were drawn to the unique visual experience offered by desert scenery, Fromentin will of course primarily focus on the visual aspect of qualisigns such as colour, light and shade. Thus shade in the desert, like silence, when attentively analysed, reveals layers of suggestiveness undreamed of in a more populated or cultivated environment:

Cette ombre des pays de lumière, tu la connais. Elle est inexprimable; c'est quelque chose d'obscur et de transparent, de limpide et de coloré; on dirait une eau profonde. Elle paraît noire, et, quand l'œil y plonge, on est tout surpris d'y voir clair. Supprimez le soleil, et cette ombre elle-même deviendra du jour. Les figures y flottent dans je ne sais quelle blonde atmosphère qui fait évanouir les contours. ${ }^{9}$

A similar depth and multiplicity of sometimes infinitesimal associations is to be found in colour, the desert sky becoming like a magical palette on which are displayed infinite variations of qualities and tones. ${ }^{10}$ But perhaps the most enduring lesson Fromentin as painter and writer learns from the desert is that it brings together qualisigns in patterns of unimaginable profusion and simultaneity. Once again, it is the sky and the various effects of weather that provide the signs that organise themselves into patterns of harmony and contrast that seem simultaneously to exhaust any further potential for representation. So in the following passage, colours, weather patterns, seasons, geological formations, coalesce and intermingle seamlessly, constantly deferring any impetus for final interpretation:

Tout ce côté du ciel était sombre et présentait l'aspect d'un énorme océan de nuages, dont le dernier flot venait pour ainsi dire s'abattre et se rouler sur l'extrême arête de la montagne. Mais la montagne, comme une solide falaise, semblait le repousser au large, et, sur toute la ligne orientale du Djebel-Sahari, il y avait un remous violent exactement pareil à celui d'une forte marée. Derrière, descendaient lugubrement les trainées grises d'un vaste déluge; puis, tout à fait au fond, une montagne éloignée montrait sa tête couverte de légers frimas. Il pleuvait à torrents dans la vallée du Metlili, et quinze lieues plus loin il neigeait. L'éternel printemps souriait sur nos têtes. ${ }^{11}$

Whereas an eternal spring is for Fromentin a utopian state that can be experienced in the Sahara desert, the diurnal rains of equatorial Amazonia are for

8. Fromentin, p. 67.

9. Fromentin, p. 152.

10. Fromentin, p. 7.

11. Fromentin, p. 8. 
the Belgian writer Henri Michaux (1899-1984) a dystopia undermining the possibility of separating out and therefore measuring or qualifying the phenomena of the exotic world. Michaux travels down the Amazon from one of its sources in Ecuador to its mouth at Belem in Brazil by boat, descending much of the river in a series of small canoes. This means of transport has a surprisingly negative impact on the writer's perception of time and space:

L'auteur ayant parcouru 527 kilomètres en canoa imaginait à Rocafuerte trouver une chaloupe à vapeur, mais elle ne part que dans un mois; il continuera donc à descendre le Napo jusqu'à l'Amazone, parcourant quelque 1.400 kilomètres en canoa, calé sous un pamakari qui est un toit de feuilles arqué, qui descend jusqu'au bord, cercueil de $38^{\circ}$ de chaleur, n'y ayant que des sacs de riz où l'on bute, et ni se peut lire ni rien, on est couché plutôt qu'assis et presque sans rien voir. ${ }^{12}$

The days and weeks spent descending the river merge into an undifferentiated blur, the span of which it is difficult to reckon in clock-time. This effect of timelessness is exacerbated by the heat ( $38^{\circ}$ centigrade) and by the poor visibility afforded by the closed-in canoe. It is limited further by the frequent tropical downpour. The presence of water as both a containing flow, a means of transport ('Pirogue trop petite et mobile. Plusieurs fois manque se coucher sur l'eau', ${ }^{13}$ ), and as the essence of the jungle environment - clouds, water vapour, downpour, condensation, rapids, currents, waves - results in Michaux being swept along an interface between two humid surfaces which do nothing but reflect each other in a complementary blur. The result of this is that measuring or separating out of time, space, or movement becomes highly problematic.

'Exotic' time only seems to Michaux to organize itself into measurable and perceptible units when it can be represented in vertical as opposed to horizontal terms. So the phenomena of the exotic real only seem to separate and organise themselves into recognisable objects and species, flora and fauna (and tropical diseases) when experienced through a climate that organises itself in geographical layers:

Le plus haut, c'est neige et glace, la calotte de nombreux volcans. La région intermédiaire (les $3.000 \mathrm{~m}$.) est encore froide et aride. Une demi-heure d'un train lent, voici une station, on vous offre des mandarines fraîches cueillies. On est piqué de quantité de mouches. On ne supporte plus le pardessus. (C'est qu'on est descendu à 2.300 mètres.) Encore quelques minutes de trajet: cannes à sucre, et quelques centaines de mètres plus bas, vers les 1.000 mètres, ce sont des ananas, bananiers, palmiers de toute espèce, singes, perroquets, typhoïde et paludisme. ${ }^{14}$

12. Michaux, p. 147.

13. Michaux, p. 138.

14. Michaux, pp. 87-88. 
Such a quasi simultaneity of difference, reminiscent of that experienced by Fromentin in the Sahara, ${ }^{15}$ is summed up by Michaux in a typically comic vignette:

Il est difficile de déterminer le climat de l'Equateur. Dans les hauts plateaux, les gens ont coutume de dire, et c'est assez juste: les quatres saisons en un jour. [...]

Aussi 1'habillement est-il une réelle difficulté pour peu que l'on soit dehors pendant plusieurs heures.

L'on voit des désespérés sortir, avec chapeau de paille, veston de toile, pelisse et parapluie. $^{16}$

Although in Amérique (1986), Jean Baudrillard (1929-2007), experiences both the timelessness of the desert as felt by Fromentin, and the difficulty of first identifying and then interpreting signs as faced by Michaux, neither of these problems is the central one for him. The problem for Baudrillard is rather the profound ambiguity of the sign itself: both its decay in the disneyfied culture in the society of radical simulation that is the present-day Unites States, and yet the persistence of its mystique in such desolate sights/sites as Death Valley. So while we find in Amérique a systematic problematisation of visual and aural signs that directly recalls the preoccupations of Fromentin and Michaux, we also find a radical interrogation of the semiotic process itself. So, in the following passage, Baudrillard not only, like Fromentin, perceives the desert as a world of qualisigns, but also sees them as floating and, in the process, undermining the whole basis of the sign/object/meaning relationship on which western understanding is based:

La couleur y est comme subtilisée et détachée de la substance, diffractée dans l'air et flottant à la surface des choses - d'où l'impression spectrale, ghostly et en même temps voilée, translucide, calme et nuancée des paysages. De là l'effet du mirage, mirage du temps aussi, si proche de l'illusion totale. Les roches, les sables, les cristaux, les cactus sont éternels, mais aussi éphémères, irréels et détachés de leur substance. [...] Par contre, la lumière, elle, est substantielle, pulvérisée dans l'air, elle donne à toutes les teintes cette nuance pastel caractéristique qui est comme l'image de la désincarnation, de la séparation de l'âme et du corps. Dans ce sens on peut parler de l'abstraction du desert. ${ }^{17}$

Here the signs of the desert, whether they are mineral, vegetable, light- or timerelated, are perceived both as icons or qualisigns - signs of essence and of quality, and as sinsigns - signs of reality and presence. They can detach themselves from their objects, sensual films or wraiths that bear their imprint while seeming to float, or they can solidify into their objects, like chemical precipitates: light becomes tangible, objects ethereal. The essential quality of desert signs is

15. Fromentin, p. 8 .

16. Michaux, p. 89.

17. Baudrillard, p. 70 . 
their undecidability, an undecidability that throws the whole nature of experience and of semiotic representation into doubt. Hence the recurrence of such terms as mirage, spectre and ghost. This fluidity of categories and qualities leads to a world not of stable objects to which signs or labels can be attached, but to a world of abstractions, one suggesting an aesthetic of qualisigns that in the twentiethcentury American tradition finds its realisation in that school of painting, the obverse of and complement to Pop Art, that is abstract expressionism.

An equivalent ambivalence characterises the aural qualisigns of the desert. So, in the silence of Death Valley, Baudrillard experiences a semiotic complexity similar to that recorded by Fromentin in the Sahara. In effect, silence becomes equivalent to, or even supersedes, time and space, abolishing the measuring and abstracting norms human beings have instituted to regulate and make comprehensible their experience:

\begin{abstract}
Mais rien n'égale, dans un autre sens, et sous le sceau du silence, la tombée de la nuit sur la Vallée de la Mort, sur la véranda devant les dunes, dans les fauteuils du motel, épuisés, transparents. La chaleur ne tombe pas, seule la nuit tombe, trouée de quelques phares d'automobiles. Le silence est inouï, ou plutôt il est tout ouïe. Ce n'est pas celui du froid, ni de la nudité, ni de l'absence de vie, c'est celui de toute la chaleur sur l'étendue minérale devant nous, sur des centaines de miles, celui du vent léger sur les boues salées de Badwater, et qui caressent les gisements métalliques du Telephon Peak. Silence intérieur à la Vallée elle-même, silence de l'érosion sousmarine, en dessous de la ligne de flottaison du temps comme en dessous du niveau de la mer. Pas de mouvement animal, rien ne rêve ici, rien ne parle de rêve, chaque soir la terre y plonge dans les ténèbres parfaitement calmes, dans le noir de sa gestation alcaline, dans la dépression bienheureuse de son enfantement. ${ }^{18}$
\end{abstract}

Time here, then, is not experienced as a gap, as a measured interval, as a calibration - diurnal, seasonal, annual, millennial - of any kind, but rather as an infinite and seamless progression in which the present moment is absorbed back into archaeological - even cosmic - time. Human consciousness is taken below the waterline of time ('la ligne de flottaison du temps') into a realm where everything merges into everything else in a shadowy movement of disarticulation. This disarticulation is reflected in Baudrillard's style and tone, which like that of Fromentin in the desert, takes the form of an elegiac play of assonance, alliteration and repetition. Baudrillard here constructs a linguistic network in which, just as in the desert certain qualities seem to become detached from their objects, so adjectives detach themselves from their nouns, the words 'épuisés, transparents' left floating in apposition after the noun 'fauteuils' in such a way that the qualities these words suggest become available for reattachment to other objects in the passage, to which, indeed, their semantic content seems as plausibly to relate them.

18. Baudrillard, pp. 70-71. 
In this way, Baudrillard, like Fromentin, confronts a landscape that transcends both space and time, a 'paysage [...] dépositaire de tous les événements géologiques et anthropologiques, jusqu'aux plus récents'. ${ }^{19}$ Death Valley thus becomes the site par excellence of the undoing of human cognitive categories:

[L]a Death Valley a quelque chose de mystérieux en soi. Quelque beauté qu'offrent les déserts de l'Utah et de la Californie réunis, celui-ci est autre chose, et de sublime. La brume de chaleur surnaturelle qui l'enveloppe, sa profondeur inverse, au-dessous du niveau de la mer, la réalité sous-marine de ce paysage, avec les surfaces de sel et les mudhills, l'encerclement des hautes montagnes, qui en fait une sorte de sanctuaire intérieur - un lieu initiatique, qui tient de la profondeur géologique et des limbes, doux et spectral. Ce qui m'a toujours frappé, c'est la douceur de la Vallée de la Mort, le pastel de ses couleurs, le voile fossile, la fantasmagorie brumeuse de son opéra minéral. Rien de funèbre, ni de morbide: une transverbération où tout est palpable, la douceur minérale de l'air, la substance minérale de la lumière, la fluide corpusculaire de la couleur, l'extraversion totale du corps dans la chaleur. Un fragment d'une autre planète (d'avant toute espèce humaine en tout cas), porteur d'une autre temporalité, plus profonde, à la surface de laquelle vous flottez, comme sur une eau lourde. Ce qui engourdit les sens, l'esprit et tout sentiment d'appartenance à l'espèce humaine, c'est d'avoir devant soi le signe pur, inaltéré, de cent quatre-vingts millions d'années, et donc l'énigme impitoyable de votre propre existence. C'est le seul endroit où il soit possible de revivre, en même temps que le spectre physique des couleurs, le spectre des métamorphoses inhumaines qui nous ont précédés, nos devenirs successifs: minéral, lumière, chaleur, tout ce que la terre a pu être, toutes les formes inhumaines par où elle est passée, réunies en une seule vision anthologique. ${ }^{20}$

For Baudrillard then, Death Valley offers an experience of the virtually presemiotic. No collateral experience (except that of a Martian or other extraplanetary consciousness) could cast light on this sign which is so pure that even the slightest connotation has been bleached out of it. The physical presence of the place, despite its 180 million years, is as spectral as the human consciousness which perceives it, the enigma of the latter being heightened not resolved in the presence of the former. Like Fromentin, Baudrillard is concerned with the geographical and the geological features of the site, but in a post-evolutionary age such features open out into a 'vision anthologique' that so far precedes human consciousness as to fade the latter out. The attitude of both writers to their respective scene is one of awe:

Les déserts naturels m'affranchissent sur les déserts du signe. Ils m'apprennent à lire en même temps la surface et le mouvement, la géologie et l'immobilité. Ils créent une vision expurgée de tout le reste, les villes, les relations, les événements, les médias. Ils induisent une vision exaltante de la désertification des signes et des

19. Baudrillard, p. 69.

20. Baudrillard, pp. 67-68. 
hommes. Ils constituent la frontière mentale ou viennent échouer les entreprises de la civilisation. Ils sont hors de la sphère de la circonférence des désirs. Il faut toujours en appeler aux déserts du trop de signification, du trop d'intention et de prétention de la culture. Ils sont notre opérateur mythique. ${ }^{21}$

The closest Baudrillard gets to a model of time as experienced in the desert is that of the cinema: desert time, like mythic time, is essentially cinematographic. 'Vous parcourez le désert comme un western'. ${ }^{22}$ Unlike so-called 'real' time, mythic time (through ritual) and cinematographic time (through rerun and playback) can be reversed, indefinitely replayed. It is a time programmed only by the framing human consciousness that directs it; it has no objective reality. In the end all experience of time is mythic because it is a function of human projection, which in modern terms becomes televisual. If deserts offer Fromentin and Baudrillard privileged examples of 'opérateurs mythiques', it is because they at the same time make extraordinarily vivid and undermine the signs that humans project onto them. ${ }^{23}$

In this way, the desert, mountain or other 'exotic' scene is able to fulfill a double semiotic function in western consciousness: on the one hand, it offers an all-inclusive, mythical synthesis of the possibilities of human experience; on the other, it undermines the validity of human categorization of phenomena whether temporal or material. Exotic time can thus take the western mind back into a pre-rationalist era while, at the same time offering a critique of the categories and divisions that form the basis of modern western scientific observation and analysis.

21. Baudrillard, p. 63.

22. Baudrillard, p. 57.

23. See David Scott, Semiologies of Travel from Gautier to Baudrillard (Cambridge: Cambridge University Press, 2004). 